\title{
Percutaneous Fixation Of Scaphoid Non-union. A systematic Review
}

\author{
Mohamed O. Hegazy, Adel S. El-Hammady, Esmail A. El-gazzar
}

\begin{abstract}
Department of orthopedic surgery, Benha faculty of Medicine, Benha University, Egypt

Correspondence to: Esmail A. El-gazzar, department of orthopedic surgery, Benha faculty of Medicine, Benha University, Egypt

email:
\end{abstract}

esmailelgazzar42@gmail.com

Received: 21 July 2019

Accepted:9 October 2019

\section{Abstract:}

The primary risk factor for nonunion of the scaphoid is displacement/instability, but delayed or missed diagnosis, inadequate treatment, fracture location, and blood supply are also risk factors. Untreated nonunion leads to degenerative wrist arthritis, the so-called 'scaphoid nonunion advanced collapse' wrist. Treatment options vary from percutaneous fixation to open reduction and internal fixation with vascularized or nonvascularized bone grafting to salvage procedures involving excision and/or arthrodesis of carpals. Percutaneous fixation of fractures of the scaphoid is well documented in the acute setting by both dorsal and volar methods. What is not commonly discussed is the use of this method for delayed unions and nonunions of the scaphoid. These techniques can avoid the morbidity of an open approach and division of the carpal ligaments. Seven studies were collected from Febuary to July 2018 on percutaneous fixation of scaphoid nonunion from PubMed, Medscape, and Google Scholar and also from materials available in the Internet covering the years between 2000 and 2017. They were included in the review, as they were deemed eligible by fulfilling the inclusion criteria. All these studies were carried out on humans and discussed the results of percutaneous fixation of scaphoid nonunion and were based on sufficient number of patients and reliable results. Healing was achieved in most cases of scaphoid nonunion treated by this method, provided that there was a good selection of cases appropriate for treatment by percutaneous fixation. Percutaneous fixation in appropriate patients provides satisfactory results with high union and minimal complication rates in scaphoid nonunions. Percutaneous screw fixation is indicated in early scaphoid nonunions without substantial cystic bone resorption, without appreciable collapse of the scaphoid architecture, and without clear avascular necrosis of the proximal pole. Moreover, the scaphoid should be with an intact external cartilaginous shell and normal scapholunate angle without a humpback deformity.

Keywords: minimally invasive, nonunion, percutaneous fixation, scaphoid, without bone graft 


\section{Introduction}

Among all wrist injuries, the incidence of fractures of the scaphoid is second only to that of fractures of the distal radius. Scaphoid fractures constitute $60-70 \%$ of all carpal bone fractures and $11 \%$ of all hand fractures ${ }^{[1]}$.

The scaphoid has several unique characteristics that affect its healing potential. Approximately $80 \%$ of the bone is covered with articular cartilage, and the scaphoid has a tenuous blood supply. The main blood supply to the scaphoid is from the radial artery. The dorsal scaphoid branches from the radial artery enter the nonarticular portion of the scaphoid at the dorsal ridge at the level of the waist and supply the proximal $70-80 \%$ of the scaphoid. The volar scaphoid branches from either the radial artery or the superficial palmar branch enter at the distal tubercle and supply the distal $20-30 \%$ of the scaphoid. Thus, the vascularity of the proximal pole depends entirely on intraosseous blood flow. This tenuous blood supply to the proximal pole of the scaphoid helps to explain the increased frequency of delayed union, nonunion, and avascular necrosis (AVN) of scaphoid fractures ${ }^{[2]}$.

Scaphoid NU is actually a not well-defined concept, but most authors agree that a NU exists if there is no evidence of scaphoid healing, at least 3 months after the initial fracture. Approximately 3-4\% of nondisplaced scaphoid fractures result in nonunion. Within the group of fractures with significant displacement, the incidence of nonunion is $46-55 \%{ }^{[3,4]}$.

Percutaneous screw fixation has been advocated for minimally displaced acute scaphoid fractures and was recently reported for displaced scaphoid fractures. A few reports have described the percutaneous approach for treating scaphoid delayed unions and nonunions $\stackrel{[5,6]}{\text {. }}$

Studies have shown that delayed or nonunion scaphoid fractures should be treated be with nternal fixation. A number of authors have suggested that selected scaphoid nonunions may heal with rigid fixation alone [7] However, open approaches, either dorsal or palmar, have certain problems including soft tissue stripping, damage to ligaments, especially the radioscaphocapitate and radiolunate ligaments, leading to instability and injury to the already damaged blood supply, leading to AVN, infection, reflex sympathetic dystrophy, painful scar formation, and stiffness ${ }^{[8]}$. For these reasons, there has been a trend toward percutaneous fixation of such fractures ${ }^{[9]}$.

We undertook a systematic review for results of percutaneous fixation of the scaphoid in case of nonunion. 


\section{Aim of the study:}

The aim of this study was to introduce a systematic review to estimate the results of percutaneous fixation of the scaphoid in case of nonunion.

\section{Materials and methods}

Search strategy

We collected papers on percutaneous fixation of scaphoid nonunion from PubMed, Medscape, and Google Scholar and also from materials available in the Internet covering the years between 2000 and 2017. We used the search terms scaphoid/percutaneous fixation/nonunion/nonunion/nonunited/withou $t$ bone graft. The search was performed in electronic databases from Febuary to July 2018.

\section{Study selection}

All studies were independently assessed for inclusion. They were included if they fulfilled the following criteria.

Inclusion criteria of published studies:

(1) Published in the English language.

(2) Published in peer-reviewed journals.

(3) Focused on percutaneous fixation of scaphoid nonunion.

\section{Data extraction}

If the studies did not fulfill the above criteria, they were excluded, such as reports without peer-review, not within the national research programme, letters, comments, editorials, news, and studies not focused on percutaneous fixation of scaphoid nonunion.

Quality assessment

The quality of all studies was assessed. Important factors included study design, attainment of ethical approval, evidence of a power calculation, specific eligibility criteria, appropriate controls, adequate information and specified assessment measures. It was expected that confounding factors would be reported and controlled for and appropriate data analysis made in addition to an explanation of missing data.

Data synthesis

A structured systematic review was performed.

\section{Results}

In total, 10 potentially relevant publications were identified; three articles were excluded, as they did not meet our inclusion criteria. A total of seven studies were included in the review, as they were deemed eligible by fulfilling the inclusion criteria. All these studies were carried out on humans and examined all the results of percutaneous fixation of scaphoid nonunion. They were reviewed from Medline databases (PubMed, Medscape). A structured systematic review was performed. 
Studies here are considered to discuss the results of percutaneous fixation of scaphoid fracture nonunion and to be based on a sufficient number of patients and reliable results, as shown in the following tables:
(1) Baseline characteristics of the included studies (Table 1 ).

(2) Results of the included studies (Table 2).

Table (1): Baseline characteristics of included studies

\begin{tabular}{|c|c|c|c|c|c|c|c|}
\hline References & $\begin{array}{c}\text { Number } \\
\text { of } \\
\text { patients }\end{array}$ & $\begin{array}{l}\text { Male : } \\
\text { female }\end{array}$ & $\begin{array}{l}\text { Patient age } \\
\text { years mean } \\
\text { (range) }\end{array}$ & $\begin{array}{c}\text { Zone of } \\
\text { nonunion or } \\
\text { delayed } \\
\text { union }\end{array}$ & $\begin{array}{l}\text { Duration of } \\
\text { fracture }\end{array}$ & Method of fixation & $\begin{array}{l}\text { Duration of } \\
\text { follow-up }\end{array}$ \\
\hline$\underset{[5]}{\text { Slade } \text { et al. }}$ & 15 & $14: 1$ & $20(17-28)$ & $\begin{array}{l}\text { Waist } 10 \\
\text { proximal } \\
\text { pole } 5\end{array}$ & $\begin{array}{c}\text { Average } 9 \\
\text { months (range: } \\
4-15 \text { months) }\end{array}$ & $\begin{array}{l}\text { Arthroscopically } \\
\text { assisted dorsal } \\
\text { percutaneous } \\
\text { screw fixation }\end{array}$ & 35 weeks \\
\hline$\underset{[8]}{\text { Saint-Cyr }}$ & 8 & $6: 2$ & $27(17-39)$ & Waist & $\begin{array}{l}\text { Average } 6 \\
\text { months }\end{array}$ & $\begin{array}{c}\text { Dorsal } \\
\text { percutaneous } \\
\text { screw fixation }\end{array}$ & $\begin{array}{c}\text { averaged } 13 \\
\text { weeks }\end{array}$ \\
\hline $\begin{array}{l}\text { Mahmoud } \\
\text { and Koptan }\end{array}$ & 27 & $26: 1$ & $28.3(20-40)$ & Waist & $\begin{array}{c}\text { Mean } 18.2 \\
\text { months (6-36 } \\
\text { months) }\end{array}$ & $\begin{array}{c}\text { Volar } \\
\text { percutaneous } \\
\text { screw fixation }\end{array}$ & $\begin{array}{l}24.6 \text { months } \\
\quad(12-39)\end{array}$ \\
\hline Capo et al. & 12 & $11: 1$ & $24(14-47)$ & Waist & $\begin{array}{l}\text { Average } 8.7 \\
\text { months (range: } \\
2-14 \text { months) }\end{array}$ & $\begin{array}{c}\text { Precutaneoous } \\
\text { screw fixation } \\
\text { Volar } 8 \text { Dorsal } 4\end{array}$ & $\begin{array}{c}35 \text { months } \\
\text { (range: } 12-96 \text { ) } \\
\text { postoperatively }\end{array}$ \\
\hline $\begin{array}{l}\text { Taskin } \\
\text { Altay }\end{array}$ & 33 & $31: 2$ & $16(25-33)$ & $\begin{array}{l}\text { Proximal } \\
\text { pole } 15 \\
\text { Waist } 18\end{array}$ & $\begin{array}{c}\text { Mean } 7.6 \\
\text { months (range: } \\
\text { 2-36 months) }\end{array}$ & $\begin{array}{c}\text { Dorsal } \\
\text { percutaneous } \\
\text { screw fixation }\end{array}$ & $\begin{array}{c}\text { (mean: } 16 ; \\
\text { range: } 7-48 \\
\text { months after the } \\
\text { operation) }\end{array}$ \\
\hline $\begin{array}{l}\text { Galal } \\
\text { Hegazy }\end{array}$ & 21 & $17: 4$ & $23(16-45)$ & Waist & $\begin{array}{l}\text { Average } 6.8 \\
\text { months (range: } \\
4-8.3 \text { months) }\end{array}$ & $\begin{array}{c}\text { Volar } \\
\text { percutaneous } \\
\text { screw fixation }\end{array}$ & $\begin{array}{c}\text { mean } 25 \\
\text { months (range: } \\
18-35)\end{array}$ \\
\hline $\begin{array}{l}\text { Gürger et } \\
\text { al. }\end{array}$ & 12 & $10: 2$ & $27(19-41)$ & $\begin{array}{l}\text { Waist } 8 \\
\text { Proximal } \\
\text { pole } 4\end{array}$ & $\begin{array}{c}\text { mean } 7.5 \\
\text { months (range: } \\
4-12 \text { months) }\end{array}$ & $\begin{array}{c}\text { Volar } \\
\text { percutaneous } \\
\text { screw fixation }\end{array}$ & $\begin{array}{c}\text { Mean } 18 \text { weeks } \\
\text { (range: } 8-36 \text { ) }\end{array}$ \\
\hline
\end{tabular}


Table (2): Results of the included studies

\begin{tabular}{lll}
\hline \multicolumn{1}{c}{ Study } & \multicolumn{1}{c}{ Results } & \multicolumn{1}{c}{ Notes } \\
\hline 1-Slade et al & All were united successfully & $\begin{array}{l}\text { average time to union was } 14 \text { weeks (range } 6 \text {-34 } \\
\text { weeks) }\end{array}$ \\
2- Michel Saint-Cyr & All were united successfully & $\begin{array}{l}\text { Average time to union was } 11 \text { weeks (range, } 6 \text { to } 28 \\
\text { weeks) for both groups combined. } \\
\text { Time to union was } 13 \text { weeks (range, } 6 \text { to } 28 \text { weeks) } \\
\text { for the nonunion group and } 7 \text { weeks (range, } 6 \text { to } 8 \\
\text { weeks) for the delayed union group }\end{array}$ \\
3- M. Mahmoud, & all fractures united & mean time to union was 11.6 weeks
\end{tabular}

W. Koptan

\section{4-John T. Capo, Ben Shamian and Marco Rizzo}

5- Taskin Altay

6-Galal Hegazy

7- M Gürger, M Yilmaz, E

Yilmaz and S Altun
-11 united successfully

-One patient with sickle cell anemia required revision fixation
-Average time to union was 4 months (range 3-6 months) in the eleven patients

- One patient with sickle cell united 3 months after revision

Pain, range of motion, grip strength and return to regular employment were evaluated and all patients had good or excellent results

average time to union was

4 months (range 3-6 months) post-screw fixation
All were united successfully without any additional procedures. -mean time to union was 15.5 weeks (range 8-30) -patient with nonunion underwent grafting with nonvascularized bone graft and union was achieved at 10 weeks.
-11 united successfully

-One patient still non-united

\section{Discussion}

Studies have shown that delayed or nonunion scaphoid fractures should be treated by internal fixation. However, open approaches, either dorsal or palmar, have certain problems including soft tissue stripping, damage to ligaments, especially the radioscaphocapitate and radiolunate ligaments, leading to instability and injury to the already damaged blood supply, leading to AVN, infection, reflex sympathetic dystrophy, painful scar formation, and stiffness $[\underline{10}, \underline{11}]$. For these reasons, there has been a trend towards percutaneous fixation of such fractures ${ }^{[\underline{8}-10]}$.

Most of the literature with regard to percutaneous fixation of scaphoid fractures is performed by the palmar approach. However, Jeon and colleagues reported a comparison of palmar and dorsal percutaneous fixation and found no difference in terms of union time 
and clinical outcome, and they concluded that the dorsal approach was better, allowing more precise placement of the screw ${ }^{[12]}$.

One of the major concerns for this approach may be the lack of grafting. However, the need for grafting for such nonunions is not certain ${ }^{[13]}$, and some additional procedures are utilized to promote healing $[\underline{[14}, \underline{15}]$. Reaming of the scaphoid in preparation for the screw creates an opportunity to establish bleeding of the bony surfaces ${ }^{[5]}$. This mechanism probably occurs for all cases united without grafting.

Slade et al. [5] proposed a progressive classification for scaphoid nonunions. This classification is a useful guide to determine the applicability of minimally invasive procedures for scaphoid nonunions [16] Minimally invasive surgery is indicated in early scaphoid nonunions without substantial cystic bone resorption, without appreciable collapse of the scaphoid architecture, and without clear AVN of the proximal pole. Additional inclusion criteria for percutaneous treatment of these nonunions should be an intact external cartilaginous shell and intact and normal scapholunate angle without a humpback deformity ${ }^{[16]}$. The integrity of the cartilage shell can be evaluated by arthroscopy or by a magnetic resonance imaging study ${ }^{[17]}$. Many publications report the use of percutaneous techniques in the treatment of delayed unions and nonunions of the scaphoid ${ }^{[5]}$ (Tables $\underline{1}$ and $\underline{2}$ ).

\section{Conclusion}

Percutaneous fixation in appropriate patients provides satisfactory results with high union and minimal complication rates in scaphoid nonunions. The percutaneous technique avoids devascularization of the scaphoid, division of the carpal ligaments, and provides a much more aesthetic scar. Percutaneous screw fixation is indicated in early scaphoid nonunions without substantial cystic bone resorption, without appreciable collapse of the scaphoid architecture, and without clear AVN of the proximal pole. Moreover, the scaphoid should be with an intact external cartilaginous shell and normal scapholunate angle without a humpback deformity.

Conflicts of interest

There are no conflicts of interest.

\section{References}

1. Sendher R, Ladd AL. The scaphoid. Orthop Clin N Am 2013; 44:107-120.

2.Young VL, Higgs PE. The injured wrist. Manual of Acute Hand Injuries. St. Louis: Mosby; 1998. 404-433.

3.Capo JT, Shamian B, Rizzo M. Percutaneous screw fixation without bone grafting of scaphoid nonunion. IMAJ 2012; 14:729-732.

4.Moritomo H, Murase T, Oka K, Tanaka H, Yoshikawa H, Sugamoto K. Relationship between the 
fracture location and the kinematic pattern in scaphoid nonunion. J Hand Surg Am 2008; 33:1459-1468.

5. Slade JF III, Geissler WB, Gutow AP, Merrell GA. Percutaneous internal fixation of selected scaphoid nonunions with an arthroscopically assisted dorsal approach. J Bone Joint Surg Am 2003; 85-A (Suppl 4):20-32.

6.Kim JK, Kim JO, Lee SY. Volar percutaneous screw fixation for scaphoid waist delayed union. Clin Orthop Relat Res 2010; 468:1066-1071.

7.Slade JFIII, Gutow AP, Geissler WB. Percutaneous internal fixation of scaphoid fractures via an arthroscopically assisted dorsal approach. J Bone Joint Surg Am 2002; 84 (Suppl 2):21-36.

8.Saint-Cyr M, Oni G, Wong C, Sen MK, LaJoie AS, Gupta A. Dorsal percutaneous cannulated screw fixation for delayed union and nonunion of the scaphoid. Plast Reconstr Surg 2011; 128:467-473.

9.Naranje S, Kotwal PP, Shamshery P, Gupta V, Nag HL. Percutaneous fixation of selected scaphoid fractures by dorsal approach. Int Orthop 2010; 34:9971003.

10. Capo JT, Shamian B, Rizzo M. Percutaneous screw fixation without bone grafting of scaphoid non-union. Isr Med Assoc J 2012; 14:729-732.
11. Jeon IH, Micic ID, Oh CW, Park BC, Kim PT. Percutaneous screw fixation for scaphoid fracture: a comparison between the dorsal and the volar approaches. J Hand Surg 2009; 34-A:228-236.

12. Gunal I, Calli I, Barton N. Current management of scaphoid fractures. Twenty questions answered. London: Royal Society of Medicine Press; 2002.

13. Buijze GA, Ochtman L, Ring D. Management of scaphoid nonunion. J Hand Surg 2012; 37- A:10951100 .

14.Bilic R, Simic P, Jelic M, Stern-Padovan R, Dodig $\mathrm{D}$, Pompe van Meerdervoort $\mathrm{R}$, et al. Osteogenic protein-1 (BMP-7) accelerates healing of scaphoid non-union with proximal pole sclerosis. Int Orthop 2006; 30:128-134.

15.Ricardo M. The effect of ultrasound on the healing of musclepediculated bone graft in scaphoid non-union. Int Orthop 2006; 30:123-127.

16. Slade JF, Dodds SD. Minimally invasive management of scaphoid nonunions. Clin Orthop Relat Res 2006; 445:108-119.

17. Streli R. Percutaneous screwing of the navicular bone of the hand with a compression drill screw (a new method). Zentralbl Chir 1970; 95:1060-1078.

To cite this article: Mohamed O. Hegazy, Adel S. El-Hammady, Esmail A. El-gazzar. Percutaneous Fixation of Scaphoid Non-union. A systematic Review. BMFJ, 2020;37(2):340-346 